\title{
Simultaneous Voltammetric Determination of Dopamine and Ascorbic Acid using Multivariate Calibration Methodology Performed on a Carbon Paste Electrode Modified by a mer-[RuCl$(\mathbf{d p p b})(4-p i c)]$ Complex
}

\author{
Poliana M. Santos, Bianca Sandrino, Tiago F. Moreira, Karen Wohnrath, Noemi Nagata and \\ Christiana A. Pessoa* \\ Departmento de Química, Universidade Estadual de Ponta Grossa, 84030-900 Ponta Grossa-PR, Brazil
}

\begin{abstract}
A preparação e caracterização eletroquímica do eletrodo de pasta de carbono (EPC) modificado com o mer $\left[\mathrm{RuCl}_{3}(\mathrm{dppb})(4-\mathrm{pic})\right]\left(\mathrm{dppb}=\mathrm{Ph}_{2} \mathrm{P}\left(\mathrm{CH}_{2}\right)_{4} \mathrm{PPh}_{2}, 4\right.$-pic $\left.=\mathrm{CH}_{3} \mathrm{C}_{5} \mathrm{H}_{4} \mathrm{~N}\right)$, denominado Rupic, foi investigada. $\mathrm{O}$ sistema EPC/Rupic apresentou apenas um par de picos com potencial médio de $0,28 \mathrm{~V} v$ s. $\mathrm{Ag} / \mathrm{AgCl}$, o qual foi atribuído ao processo de transferência de elétrons do $\mathrm{Ru}^{\mathrm{III}} / \mathrm{Ru}^{\mathrm{II}}$. Este eletrodo modificado apresentou a propriedade de eletrocatalisar a oxidação da dopamina (DA) e do ácido ascórbico (AA) em $0,35 \mathrm{~V}$ e $0,30 \mathrm{~V}$, respectivamente. Como a oxidação dos analitos, AA e DA, ocorreu praticamente no mesmo potencial, não foi possível a distinção dos sinais voltamétricos utilizando-se a voltametria cíclica. Esta limitação foi resolvida empregando-se a Regressão de Mínimos Quadrados Parciais (PLSR), a qual permitiu a determinação de quatro amostras sintéticas, com erros de previsão (RMSEP) de $5,55 \times 10^{-5}$ mol L-1 e $7,48 \times 10^{-6} \mathrm{~mol} \mathrm{~L}^{-1}$ para DA e AA, respectivamente.
\end{abstract}

The preparation and electrochemical characterization of a carbon paste electrode (CPE) modified with mer-[Ru0Cl$(\mathrm{dppb})(4-\mathrm{pic})]\left(\mathrm{dppb}=\mathrm{Ph}_{2} \mathrm{P}\left(\mathrm{CH}_{2}\right)_{4} \mathrm{PPh}_{2}, 4-\mathrm{pic}=\mathrm{CH}_{3} \mathrm{C}_{5} \mathrm{H}_{4} \mathrm{~N}\right)$, referred to as Rupic, were investigated. The CPE/Rupic system displayed only one pair of redox peaks, with a midpoint potential at $0.28 \mathrm{~V} v s$. $\mathrm{Ag} / \mathrm{AgCl}$, which were ascribed to $\mathrm{Ru} \mathrm{u}^{\mathrm{II}} / \mathrm{Ru} \mathrm{u}^{\mathrm{II}}$ charge transfer. This modified electrode presented the property of electrocatalysing the oxidation of dopamine (DA) and ascorbic acid (AA) at $0.35 \mathrm{~V}$ and $0.30 \mathrm{~V}$ vs. $\mathrm{Ag} / \mathrm{AgCl}$, respectively. Because the oxidation for both AA and DA practically occurred at the same potential, distinguishing between them was difficult with cyclic voltammetry. This limitation was overcome using Partial Least Square Regression (PLSR), which allowed us, with the optimised models, to determine four synthetic samples with prediction errors (RMSEP) of $5.55 \times 10^{-5} \mathrm{~mol} \mathrm{~L}^{-1}$ and $7.48 \times 10^{-6} \mathrm{~mol} \mathrm{~L}^{-1}$ for DA and AA, respectively.

Keywords: carbon paste electrodes, ruthenium complexes, dopamine, ascorbic acid, multivariate calibration methodology

\section{Introduction}

Considerable progress has been made over the last few years on chemically modified carbon paste electrodes, having an easier and faster procedure to assemble and renew the paste surfaces, low cost, background currents and possibility to incorporate a series of materials. ${ }^{1-5}$ Among the materials that may be used in conjunction with carbon paste are the ruthenium-containing compounds such as oxides, mixed valence compounds and complexes. These Ru-based materials possess electrocatalytic properties, which have been used to modify electrodes

*e-mail: capessoa@uepg.br for electroanalysis of ascorbic acid, ${ }^{6,7}$ L-dopa,${ }^{8}$ glucose, ${ }^{9}$ benzylic compounds ${ }^{10}$ and dopamine. ${ }^{11}$ Dopamine (DA) and ascorbic acid (AA), in particular, are relevant from the biomedical and neurochemical point of view, for their importance to human metabolism. DA is involved in the functioning of the central nervous system, in addition to the cardiovascular, renal and hormonal systems, and plays an important role in drug addiction and Parkinson's disease. ${ }^{12,13}$ Similarly, AA (vitamin C) has been used in preventing and treating cold, mental illness, infertility, cancer and other diseases. ${ }^{14}$ In the mammalian brain, AA is present along with several neurotransmitters including dopamine, with a concentration of 100-1000 times higher than that of DA. The coexistence of ascorbic acid (AA) 
makes it difficult to detect dopamine electrochemically because AA can be easily oxidized at a potential close to that of DA. Furthermore, oxidized DA mediates AA oxidation and the electrode surface can be easily fouled by the product of AA oxidation.

In order to distinguish between DA and AA, various methods to prepare electrodes have been developed, as modified carbon nanotubes, ${ }^{15,16}$ sol-gel composites, ${ }^{17}$ selfassembled monolayers, ${ }^{18}$ polymer films, ${ }^{19}$ modified carbon paste ${ }^{20}$ and electrochemically pretreated glassy carbon electrodes. ${ }^{21}$ Carbon-based electrodes have been used to study the electrochemical oxidation of DA because noble metal electrodes are easily contaminated. ${ }^{22}$ In many of these cases, the use of multivariate calibration methods is an alternative to reduce the interferent effect, improving the selectivity of these instrumental methods. ${ }^{23-26}$ This method can be useful for simultaneous determination of dopamine and ascorbic acid when only the modification of the electrode surface is not sufficient to separate significantly the oxidation peaks of both substrates. To our knowledge multivariate calibration methodology has not been combined with voltammetry for the separation of dopamine and ascorbic acid.

A multivariate calibration process consists of calibration (detection of anomalous samples and model optimization) and prediction (unknown samples analysis) steps. In the calibration step a mathematical model is developed with determination of the regression coefficient vector $\boldsymbol{b}$ ) that can reproduce a concentration matrix $\boldsymbol{Y}$ (containing $n$ rows which correspond to samples and $q$ columns of concentrations for each analyte) from a matrix $\boldsymbol{X}$ (with $n$ rows of samples and $p$ columns of current intensity obtained by the potential change). Subsequently, this model is used to estimate the concentration of elements in new samples from their voltammetric data (Figure 1). ${ }^{27}$

In this paper, a new carbon paste electrode modified with a complex mer-[RuCl$\left.{ }_{3}(\mathrm{dppb})(4-\mathrm{MePy})\right]$ (where $\mathrm{dppb}=\mathrm{PPh}_{2}\left(\mathrm{CH}_{2}\right)_{4} \mathrm{PPh}_{2} ; 4-\mathrm{Mepy}=4$-methylpyridine $)$,

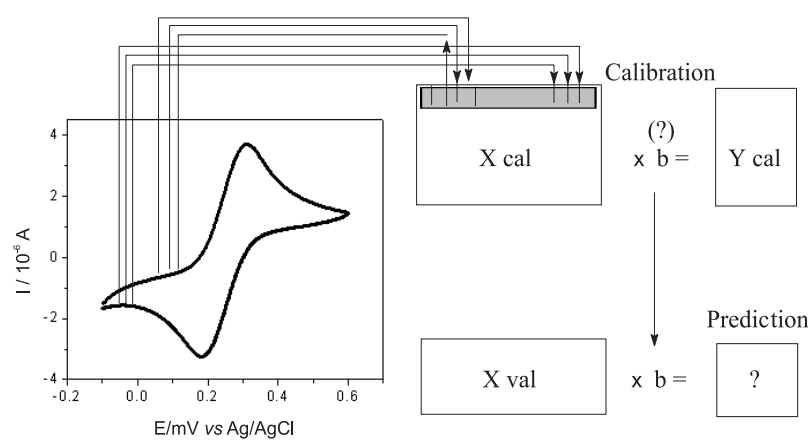

Figure 1. Data organization and multivariate calibration process. referred to as RuPic, was prepared. Electrochemical studies of the Rupic-modified electrode were carried out, also focusing on the electrocatalytic activity of the electrode toward electron transfer of ascorbic acid and dopamine. Simultaneous voltammetric determination of dopamine and ascorbic acid on the modified electrode was made using multivariate calibration methodology.

\section{Experimental}

\section{Synthesis of the Rupic complex}

The complex Rupic (mer-[RuCl$\left.{ }_{3}(\mathrm{dppb})(4-\mathrm{MePy})\right]$ (where $\mathrm{dppb}=\mathrm{PPh}_{2}\left(\mathrm{CH}_{2}\right)_{4} \mathrm{PPh}_{2} ; 4-\mathrm{MePy}=4$-methylpyridine) (shown in Figure 2), was synthesized according to the procedure previously described..$^{28}$

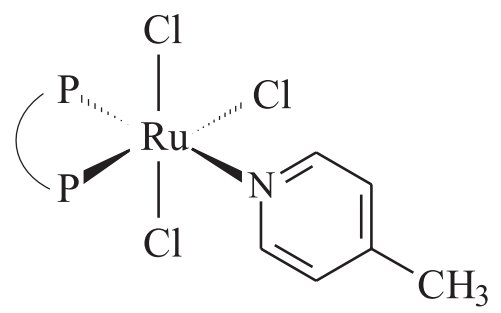

Figure 2. Molecular structure of the $m e r-\left[\operatorname{RuCl}_{3}(\mathrm{dppb})(4-\mathrm{MePy})\right]$.

Preparation of the carbon paste electrode modified with the Rupic complex (CPE/Rupic)

The assembling of unmodified carbon paste electrode (CPE) was made by mixing the graphite powder (Fluka) and drops of hydrocarbon oil (Nujol ${ }^{\circledR}$ ).

The modified carbon paste electrode (CPE/Rupic) was prepared by mixing the complex Rupic with graphite (Fluka) in a 1:25 proportion (mass/mass), respectively. To this mixture, drops of $\mathrm{Nujol}^{\circledR}$ were added. The pastes were placed in a $1 \mathrm{~mm}$ deep cavity in contact with a platinum disk having a $0.5 \mathrm{~cm}$ diameter, fused to a glass tube.

\section{Electrochemical measurements}

All the voltammetric measurements were carried out in a potentiostat MQPG-01 model, using a $10 \mathrm{~mL}$ electrochemical cell with the conventional three electrode system: a Pt wire as a counter electrode, an $\mathrm{Ag} / \mathrm{AgCl}$ electrode as the reference, and the modified carbon paste electrode as working electrode. The measurements were made in the potential range from $-0.1 \mathrm{~V}$ to $0.6 \mathrm{~V}$ vs. $\mathrm{Ag} /$ $\mathrm{AgCl}$, with scan rates in the range between $10 \mathrm{mV} \mathrm{s}^{-1}$ and $100 \mathrm{mV} \mathrm{s}^{-1}$. Solutions of various $\mathrm{pHs}$ were used, adjusted 
with $\mathrm{HCl}$ and $\mathrm{KOH}$ in a $0.5 \mathrm{~mol} \mathrm{~L}^{-1} \mathrm{KCl}$ (different supporting electrolytes were also tested). The response of the electrode in the presence of dopamine (DA) and ascorbic acid (AA) was also studied by cyclic voltammetry in $\mathrm{KCl}$ solutions at different $\mathrm{pHs}$. Several concentrations of DA and AA were used to obtain a calibration curve in the range between $4.0 \times 10^{-5}$ and $1.2 \times 10^{-3} \mathrm{~mol} \mathrm{~L}^{-1}$.

\section{Multivariate calibration methodology}

A PC/Pentium IV microcomputer equipped with the mathematical software MATLAB for Windows (version 4.2, distributed by MathWorks) and PLS-toolbox (version 1.5, distributed by Eigenvector Research) were employed to obtain the PLSR models. Known amounts of the working solutions (ascorbic acid: $1.0 \times 10^{-2} \mathrm{~mol} \mathrm{~L}^{-1}$ and dopamine: $1.0 \times 10^{-2} \mathrm{~mol} \mathrm{~L}^{-1}$ or $1.0 \times 10^{-3} \mathrm{~mol} \mathrm{~L}^{-1}$ ) were placed in a $10 \mathrm{~mL}$ volumetric flask. The $\mathrm{pH}$ was adjusted with diluted $\mathrm{HCl}$ and completed to the final volume with $\mathrm{KCl} 0.5 \mathrm{~mol} \mathrm{~L}^{-1}$. The final concentration of these solutions varied between $1.0 \times 10^{-5}$ and $5.0 \times 10^{-4} \mathrm{~mol} \mathrm{~L}^{-1}$ for dopamine and $1.0 \times 10^{-4}$ and $8.0 \times 10^{-4} \mathrm{~mol} \mathrm{~L}^{-1}$ for ascorbic acid. All the solutions were prepared with distilled water and all chemicals used were of analytical-reagent grade.

The experimental design used to develop the multivariate calibration model for dopamine and ascorbic acid is presented in Figure $3(\bullet)$. The validation set was created by selection of 4 samples from the experimental design, also shown in Figure $3(\odot)$.

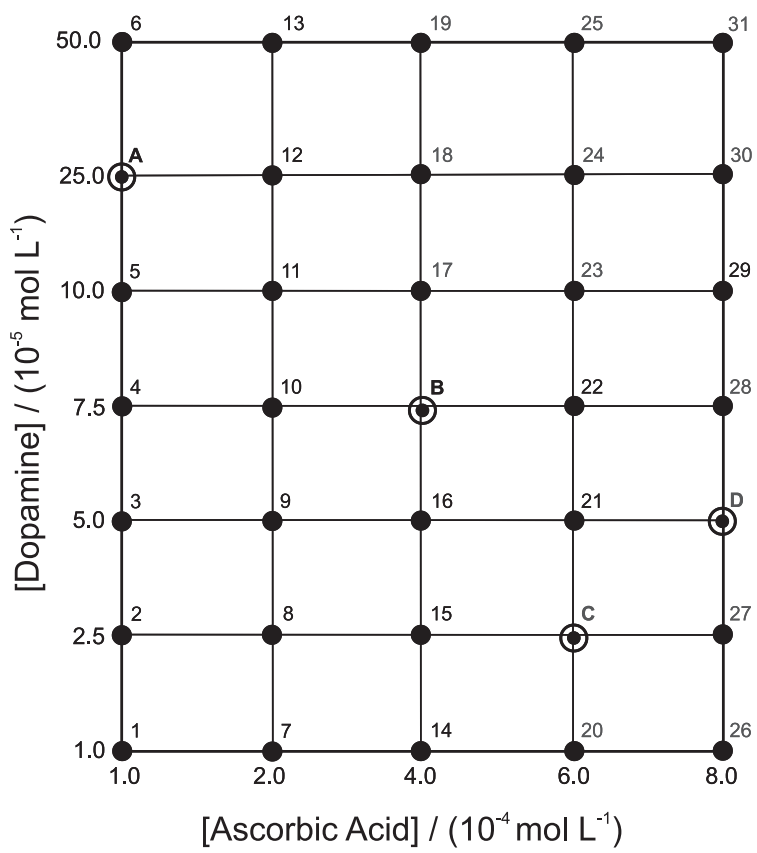

Figure 3. Composition of Synthetic Mixtures of Dopamine and Ascorbic Acid: $(\bullet)$ samples used for calibration set; $(\odot)$ samples used for external validation.

\section{Results and Discussion}

As the Rupic complex is insoluble in aqueous solutions, it can be easily incorporated into the carbon paste without leaching out from the electrode surface, thus leading to a chemically modified electrode that may be very stable. First, the electrochemical behavior of the Rupic modified electrode, referred to as CPE/Rupic, was investigated. Figure 4 shows the cyclic voltammograms for the modified electrode (CPE/Rupic) at different scan rates in $0.5 \mathrm{~mol} \mathrm{~L}^{-1} \mathrm{KCl}$ at $\mathrm{pH} 2$. A pair of reversible peaks was observed at $\mathrm{E}_{\mathrm{pa}}=0.32 \mathrm{~V}$ and $\mathrm{E}_{\mathrm{pc}}=0.24 \mathrm{~V}$ vs. $\mathrm{Ag} / \mathrm{AgCl}$, with a midpoint potential of $\mathrm{E}_{\mathrm{m}}=0.28 \mathrm{~V} v s$. $\mathrm{Ag} / \mathrm{AgCl}$. This process is usually assumed to be a singleelectron reduction/oxidation of the couple $\mathrm{Ru}(\mathrm{III}) / \mathrm{Ru}(\mathrm{II}){ }^{29}$ The redox behavior of CPE/Rupic was different from that in non aqueous solutions, for which various redox waves appear. ${ }^{28}$ The presence of only one redox process is probably due to the complex being kinetically hindered in the carbon paste..$^{10} \mathrm{~A}$ linear correlation was obtained between the anodic peak currents and the scan rate indicating that the complex is strongly incorporated into the carbon paste. This also demonstrated that the electron transfer process is a surface confined (or controlled) process.

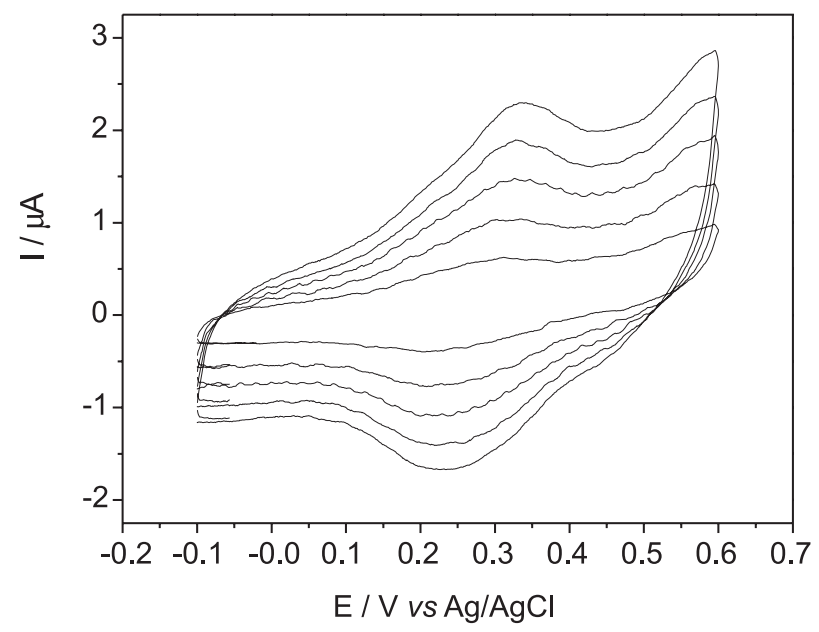

Figure 4. Cyclic voltammograms for CPE/Rupic at different scan rates: 20, 40, 60, 80 and $100 \mathrm{mV} \mathrm{s}^{-1}$. Supporting electrolyte: $\mathrm{KCl} 0.5 \mathrm{~mol} \mathrm{~L}^{-1}$ at pH 2.

The electrochemical behavior of the carbon paste electrode modified with Rupic was studied over a $\mathrm{pH}$ range between 1 and 7 and a potential range from $-0.1 \mathrm{~V}$ to 0.6 $\mathrm{V}$ vs. Ag/AgCl. The voltammetric responses with higher current peaks were obtained at $\mathrm{pH}$ below 3 . Above this $\mathrm{pH}$, no redox peaks were observed (results not shown). The potential values (anodic and cathodic) did not significantly change with the $\mathrm{pH}$ (in the range between 
0.5-3). This behavior may be explained due to the $\mathrm{H}^{+}$ions only facilitate the electron transfer between the Rupic complex and the electrode surface at low pHs. The modified electrode response was stable, i.e. the midpoint potential and the anodic and cathodic current peaks remained practically constant and did not show any significant change even after 100 potential cycles (Figure 5). Therefore, Rupic is stable and strongly incorporated in the carbon paste.

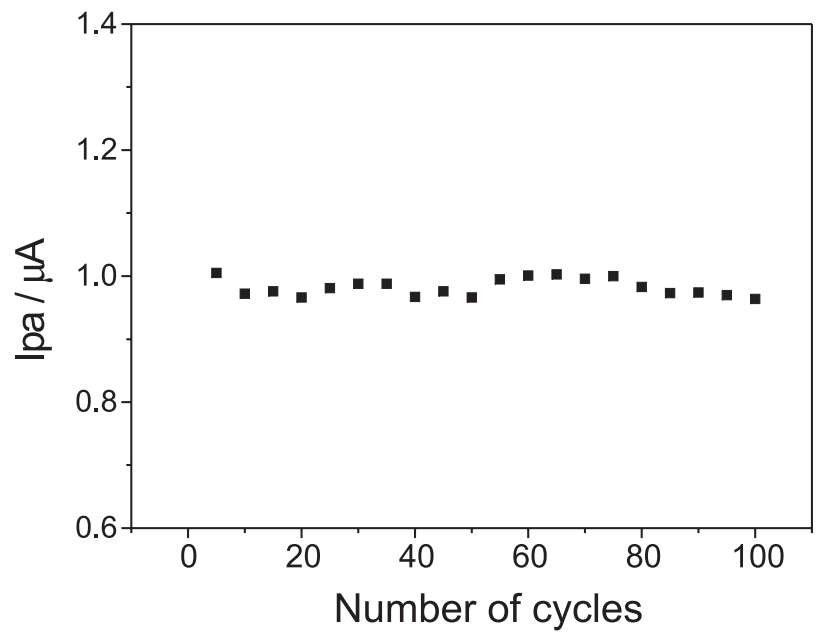

Figure 5. Stability test of the $\mathrm{CPE} / \mathrm{Rupic}$ at $30 \mathrm{mVs}^{-1}$. Supporting electrolyte: $\mathrm{KCl} 0.5 \mathrm{~mol} \mathrm{~L}^{-1}$ at $\mathrm{pH} 2$.

\section{Electrocatalytic oxidation of dopamine and ascorbic acid}

Because both DA and AA are oxidisable compounds, their detection can be made by electrochemical methods based on anodic oxidation. However, AA and DA are oxidized at nearly the same potential with poor sensitivity at solid unmodified electrodes. The use of chemically modified electrodes greatly increases the selectivity and sensitivity toward these analytes. For the CPE/Rupic electrode, in the presence of AA, Figure 6 shows considerable increase in the anodic current at $\mathrm{E}_{\mathrm{pa}}=0.32$ $\mathrm{V}$, with a decrease in the reduction peak in reversal scan direction, which is typical of electrocatalytic processes. For DA, when using the CPE/Rupic electrode, a pair of defined peaks appeared at $\mathrm{E}_{\mathrm{pa}}=0.35 \mathrm{~V}$ and $\mathrm{E}_{\mathrm{pc}}=0.05 \mathrm{~V}$ (Figure 7) with a separation of the peaks $\Delta \mathrm{E}_{\mathrm{p}}=\mathrm{E}_{\mathrm{pa}}-\mathrm{E}_{\mathrm{pc}}=$ $0.30 \mathrm{~V}$. According to the literature, ${ }^{30}$ this redox pair is associated with the oxidation/reduction of DA to the dopaminequinone with participation of two electrons.

The peaks for DA and AA were also observed for the unmodified carbon paste. However, we observed that both AA and DA oxidized in the bare CPE in the same potential as for CPE/Rupic, although the peak currents were much higher for the modified electrode (CPE/Rupic). For this

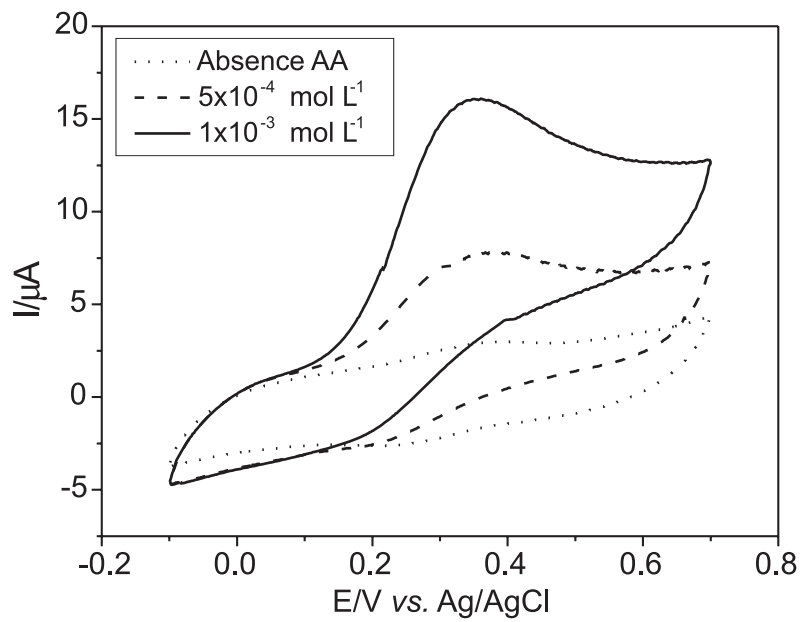

Figure 6. Cyclic voltammograms obtained with the CPE/Rupic in $\mathrm{KCl}$ $0.5 \mathrm{~mol} \mathrm{~L}^{-1}$ at $\mathrm{pH} 2$ : In the absence of AA and in presence of $5 \times 10^{-4} \mathrm{~mol} \mathrm{~L}^{-1}$ AA or $1 \times 10^{-3} \mathrm{~mol} \mathrm{~L}^{-1} \mathrm{AA}$.

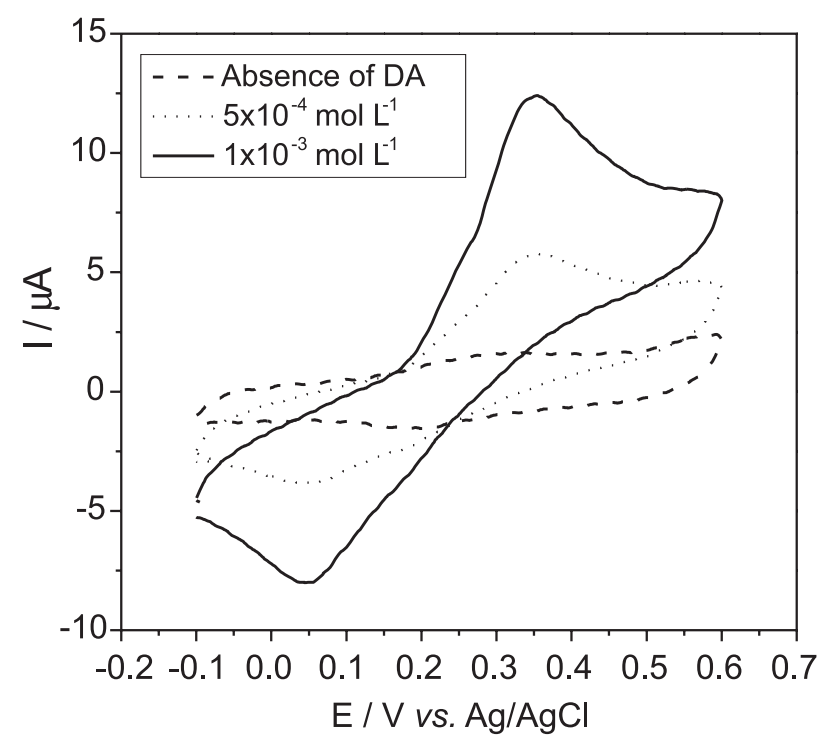

Figure 7. Cyclic voltammograms obtained with $\mathrm{CPE} / \mathrm{Rupic}$ in $\mathrm{KCl} 0.5$ mol L-1 at $\mathrm{pH} 2$ : In the absence of DA and in presence of $5 \times 10^{-4} \mathrm{~mol} \mathrm{~L}^{-1}$ DA or $1 \times 10^{-3} \mathrm{~mol} \mathrm{~L}^{-1} \mathrm{DA}$.

reason, to confirm the electrocatalytic effect of the CPE/ Rupic, the plot of $\mathrm{i}_{\mathrm{pa}} / \mathrm{v}^{1 / 2} v s$. $v$ (where $v$ is the scan rate and $i_{\mathrm{pa}}$ the oxidation current) was obtained for both analytes and a nonlinear relationship was observed. According to Nicholson and Shain, ${ }^{31}$ these results are typical for electrocatalytical systems indicating that ruthenium complex incorporated into the carbon paste facilitates electron transfer between DA (or AA) and the electrode surface, increasing the sensitivity of the electrode. The stability of CPE/Rupic was tested in the presence of DA and AA and no significant changes were observed in the response after the electrodes were used, which rules out the possibility of strong adsorption of DA or AA oxidation products onto the electrodes. Similar results were obtained for Langmuir-Blodgett (LB) films containing a mixture 
between polyaniline (PANI) and a complex mer$\left[\mathrm{RuCl}_{3}(\mathrm{dppb})\right.$ (pyridine) $] .{ }^{11}$

The analytical parameters (LOD, Sensitivity, Linear Regression Equation, Linear Range of Concentration) related to the individual determination of dopamine and ascorbic acid by cyclic voltammetry and carbon paste electrode modified by a $m e r-\left[\mathrm{RuCl}_{3}(\mathrm{dppb})(4\right.$-pic)] complex are summarized in Table 1 . The plots of the anodic current peak against AA or DA concentrations were linear in a wide range of concentration, observing a better sensitivity for DA.

\section{Multivariate Methodology}

The CPE/Rupic electrode did not present separation of the oxidation peaks between DA and AA when these compounds were simultaneously added in the electrochemical cell, unlike observed by other authors. ${ }^{17,19}$ For example, Ravi et al. ${ }^{17}$ observed a difference between the two potentials for AA and DA of $250 \mathrm{mV}$ in a mixture, using a sol-gel composite electrode. Selvaraju and Ramaraj ${ }^{19}$ found a difference of $c a .200 \mathrm{mV}$ in a glassy carbon electrode modified with polyazine. In our work, the interference problems between oxidation signals of DA and AA are illustrated in Figures 6 and 7, which is especially critical for the overlapping analytical signals of dopamine $\left(\mathrm{E}_{\mathrm{pa}}=0.35 \mathrm{~V}\right)$ and ascorbic acid $\left(\mathrm{E}_{\mathrm{pa}}=0.32 \mathrm{~V}\right)$.

In the calibration step, the set of voltammograms for 31 standard mixtures (Xcal compose by 31 lines and 1501 columns) was correlated with the corresponding concentrations. This set of voltammograms was pre-processed by the mean centered method without any other transforming procedure. To choose the latent variables in the calibration model, a cross validation procedure was employed. In this procedure, each sample from the calibration set was removed one at a time, being treated as a prediction object. All the calibration objects were treated as prediction objects at least once, and the estimated Prediction Residual Error Sum of Squares (PRESS) was used to determine the number of latent variables necessary to establish the most suitable model (Figure 8). Ideally, the predictive ability of a model must be tested by introduction of new samples (external validation set). However, in many cases cross validation gives sufficient information on the predicting capacity of a model. ${ }^{32}$ Figure 8 indicates that the lowest value for the

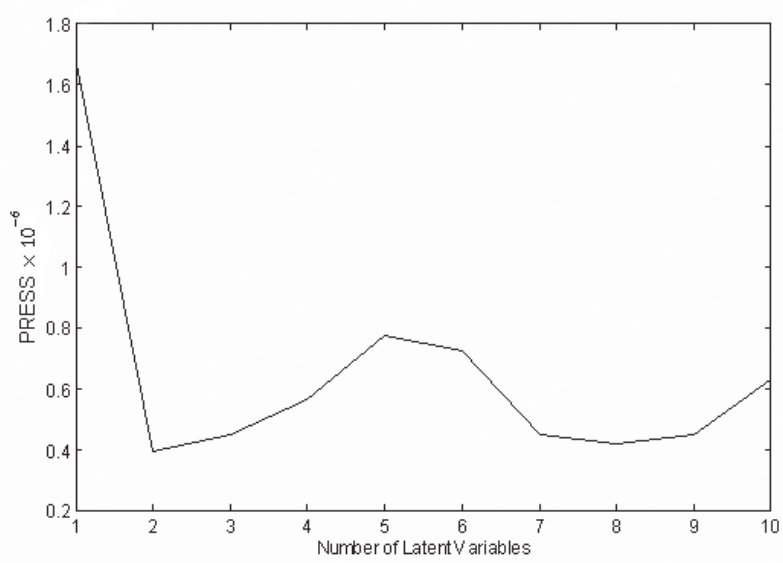

Figure 8. PRESS as a function of the number of latent variables.

PRESS is obtained with two latent variables. Statistic processing shows that the PLSR2 model with 2 latent variables explains approximately $88.1 \%$ of the variance from the data set.

The detection method to determine anomalous samples uses the Studentized residue that eliminates samples with residues $>2.5 .^{33}$ With this criterion, standard 11 was removed from the data set (high value of residue to prediction > 3.5). After removing this outlier, a new model was obtained. By plotting the residues as a function of the leverage (a measure of the influence that a sample has on the model), as shown in Figure 9, a few anomalous samples were observed. According to the literature ${ }^{33}$ standards with leverage values greater than $3 \mathrm{p} / \mathrm{n}$ ( $\mathrm{p}$ is the optimum number of latent variables in the model and $n$ is

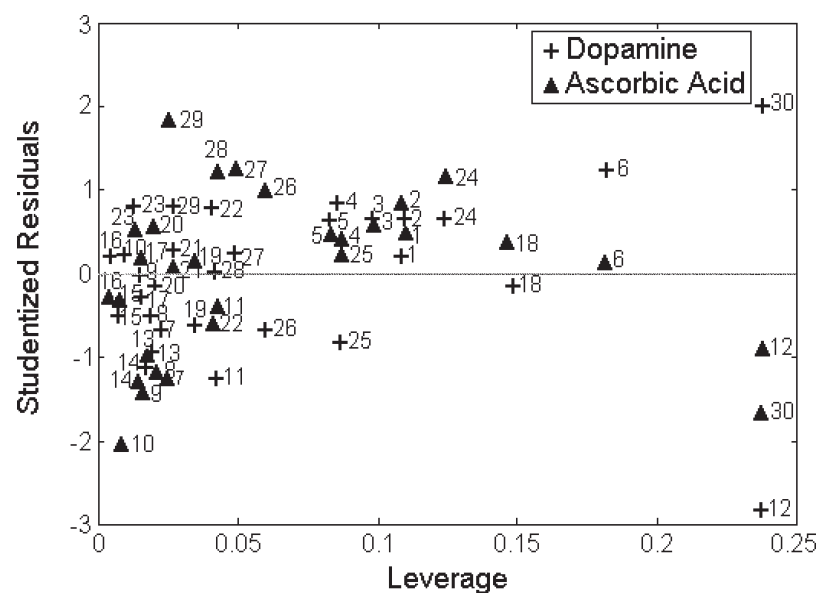

Figure 9. Studentized residuals as a function of leverage.

Table 1. Analytical parameters in determination of dopamine (DA) and ascorbic acid (AA)

\begin{tabular}{lcccc}
\hline Analyte & LOD / $\left(\mathrm{mmol} \mathrm{L}^{-1}\right)$ & $\begin{array}{c}\text { Sensitivity / } \\
\left.(\mathrm{mA} \mathrm{mol} \mathrm{L})^{-1}\right)\end{array}$ & Linear Regression Equation & $\begin{array}{c}\text { Linear Range of } \\
\left.\text { Concentration } /(\mathrm{mmol} \mathrm{L})^{-1}\right)\end{array}$ \\
\hline $\mathrm{DA}$ & 20.8 & $4.5 \times 10^{4}$ & $\mathrm{y}=0.47185+45276 \mathrm{x}$ & 5 to 50 \\
$\mathrm{AA}$ & 44.8 & $2.0 \times 10^{4}$ & $\mathrm{y}=0.44783+20357 \mathrm{x}$ & 5 to 50 \\
\hline
\end{tabular}


the number of calibration standards) and residuals $>2.5$ are considered anomalous samples. For this case, the leverage limit value is 0.20 , and standard 12 (corresponding to standard 13 of the initial calibration set) is an outlier by leverage and residues.

A new model was developed (now with 29 standard mixtures) under identical conditions such as the ones used in the validation procedure. Even with the same number of latent variables (with similar PRESS and increasing of percent variance explained $90.3 \%$ ), the prediction ability of the model was better in the absence of the outliers (standards 11 and 13). The concentrations predicted by the models are very close to the real concentrations, as shown in Figure 9, which indicates the validity of the calibration model.

Using the PLSR2 model developed here, four synthetic mixtures were analyzed (Xval compose by 4 lines and 1501 columns). The multivariate calibration models allow a simultaneous determination of dopamine and ascorbic acid with the relative errors reduced (Table 2), even if anodic and cathodic signals presented considerable overlapping. This demonstrates that the model is suitable for particular case where distinction of interfering and analytes is difficult.

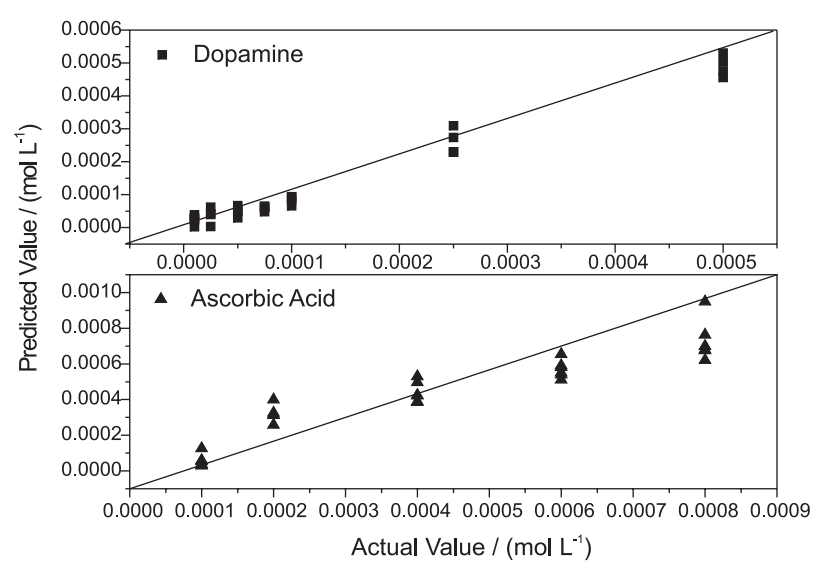

Figure 10. Actual vs. Predicted Values for Ascorbic Acid and Dopamine concentrations after data treatment by PLSR model.
These results showed relative errors greater than that obtained by Ravi et al., ${ }^{17}$ for which the peaks for the oxidation of ascorbic acid and dopamine were well resolved. However, in our work the multivariate calibration methodology was effective in determining these species, which presented serious problems of the overlapping of oxidations signals. The performance of this mathematical methodology would be even better if the voltammetric peaks did not show a shift to positive potentials with an increase in the analyte concentration.

\section{Conclusions}

The carbon paste electrode modified with Rupic complex was considerably stable. This electrode is simple, ease to prepare and renew its surface. The redox behavior of Rupic incorporated in the carbon paste was different from that observed in non aqueous solutions. The immobilized complex is not useful in selective oxidations of dopamine and ascorbic acid due to overlapping of the oxidation peaks of these species, but the electrode presented an increase in sensitivity in comparison with the unmodified electrode. The problem of separating the oxidation peaks of dopamine and ascorbic acid was resolved by using the multivariate calibration methodology. The latter methodology proved to be powerful for simultaneous quantification of AA and DA, especially considering the similarity of voltammetric response of the analytes. The results obtained were satisfactory with prediction of relative errors less than $20 \%$ for AA and $12 \%$ for DA, with no need of previous separations. Furthermore, the immobilization simplicity in a conductive matrix opens up the possibility of using Rupic in electrocatalysis of other species.

\section{Acknowledgments}

The authors are grateful to $\mathrm{CNPq}$ and Fundação Araucária (Brazil) for the financial support.

Table 2. Simultaneous determination by PLSR2 of the ascorbic acid (AA) and dopamine (DA)

\begin{tabular}{|c|c|c|c|c|c|c|}
\hline \multirow[b]{2}{*}{ Samples } & \multicolumn{2}{|c|}{$\begin{array}{l}\text { Real Concentration / } \\
\qquad\left(\mathrm{mol} \mathrm{L}^{-1}\right)\end{array}$} & \multicolumn{2}{|c|}{$\begin{array}{l}\text { Predicted Concentration / } \\
\qquad\left(\mathrm{mol} \mathrm{L}^{-1}\right)\end{array}$} & \multicolumn{2}{|c|}{ Relative Error/(\%) } \\
\hline & AA & DA & $\mathrm{AA}$ & $\mathrm{DA}$ & AA & DA \\
\hline SmpA & $1.00 \times 10^{-4}$ & $2.50 \times 10^{-4}$ & $9.66 \times 10^{-5}$ & $2.56 \times 10^{-4}$ & -3.40 & 2.56 \\
\hline SmpB & $4.00 \times 10^{-4}$ & $7.50 \times 10^{-5}$ & $4.12 \times 10^{-4}$ & $8.32 \times 10^{-5}$ & 2.90 & 10.9 \\
\hline SmpC & $6.00 \times 10^{-4}$ & $2.50 \times 10^{-5}$ & $5.47 \times 10^{-4}$ & $2.92 \times 10^{-5}$ & -8.90 & 16.8 \\
\hline SmpD & $8.00 \times 10^{-4}$ & $5.00 \times 10^{-5}$ & $8.97 \times 10^{-4}$ & $4.01 \times 10^{-5}$ & 12.1 & -19.8 \\
\hline $\begin{array}{l}\text { RMSEP / } \\
\left(\mathrm{mg} \mathrm{L}^{-1}\right)^{*}\end{array}$ & & & & & $5.55 \times 10^{-5}$ & $7.48 \times 10^{-6}$ \\
\hline
\end{tabular}

$* \operatorname{RMSEP}=\left(\Sigma\left(\mathrm{y}_{\text {pred }}-\mathrm{y}_{\text {real }}\right) / \mathrm{n}\right)^{1 / 2}$. 


\section{References}

1. Kubota, L. T.; Gushikem, Y.; Gorton, L.; J. Electroanal. Chem. 1997, 431, 23.

2. Fujiwara, S. T.; Pessoa, C. A.; Gushikem, Y.; Electrochim. Acta 2003, 48, 3625.

3. Fujiwara, S. T.; Gushikem, Y.; Pessoa, C. A.; Nakagaki, S.; Electroanalysis 2005, 17, 783.

4. Walcarius, A.; Mariaulle, P.; Lamberts L.; J. Solid State Electrochem. 2003, 7, 671.

5. Sotomayor, M. P. T.; Tanaka, A. A.; Kubota, L. T.; Electroanalysis 2003, 5, 787.

6. Ramos, L. A.; Cavalheiro, E. T. G.; Chierice, G. O.; Il Farmaco 2005, 60, 149.

7. Nalini, B.; Sriman Narayanam, S.; Anal. Chim. Acta 2000, 405, 93.

8. Teixeira, M. F. S.; Bergamini, M. F.; Marques, C. M. P.; Bocchi, N.; Talanta 2004, 631083.

9. Ivanova, E. V.; Sergeeva, V. S.; Oni, J.; Kurzawa, C.; Ryabov, A. D.; Schumann, W.; Biolectrochemistry 2003, 60, 65.

10. Lima, E. C.; Fenga, P. G.; Romero, J. R.; De Giovani, W. F.; Polyhedron 1998, 17, 313.

11. Ferreira, M.; Dinelli, L. R.; Wohnrath, K.; Batista, A. A.; Oliveira, O. N.; Thin Solid Films 2003, 446, 301.

12. Wightman, R. M.; May, L. J.; Michael, A. C.; Anal. Chem. 1988, 60, A769.

13. O’Neill, R. D.; Analyst 1994, 119, 767.

14. Arrigoni, O.; De Tullio, M. C.; Biochim. Biophys. Acta-Gen. Subj. 2002, 1569, 1.

15. Zhang, M.; Gong, K.; Zhang, H.; Mao, L.; Biosens. Bioelectron. 2005, 20, 1270.

16. Zhao, Y.; Gao, Y.; Zhan, D.; Liu, H.; Zao, Q.; Kou, Y.; Shao, Y.; Li, M.; Zhuang, Q.; Zhu, Z.; Talanta 2005, 66, 51.

17. Ravi Shankaran, D.; Iimura, K.; Kato, T.; Sens. Actuators, $B$ 2003, 94, 73.
18. Liu,T.; Li, M.; Li, Q.; Talanta 2004, 63, 1053.

19. Selvaraju, T.; Ramaraj, R.; Electrochem. Commun. 2003, 5 , 667.

20. Zare, H. R.; Nasirizadeh, N.; Mazloum Ardakani, M.; J. Electroanal. Chem. 2004, 577, 25.

21. Gu, H.; Xu, Y.; Peng, W.; Li, G.; Chen, H-Y.; Microchim. Acta 2004, 146, 223.

22. Zhao, H.; Zhang, Y.; Yuan, Z.; Anal. Chim. Acta 2001, 441, 117.

23. Hejazi, L.; Mohammadi, D. E.; Yamini, Y.; Brereton, R. G.; Talanta 2004, 62, 183.

24. Zagonel, G. F.; Peralta-Zamora, P.; Ramos, L. P.; Talanta 2004, 63, 1021.

25. Matos, R. C.; Angnes, L.; Araújo, M. C. U.; Saldanha, T. C. B.; Analyst 2000, 125, 2011.

26. Lemberge, P.; Van Espen, P. J.; Verbos, B. A. R.; X-ray Spectrom. 2000, 29, 297.

27. Nagata, N.; Bueno, M. I. M. S.; Peralta-Zamora, P.; Quim. Nova 2001, 24, 531.

28. Wohnrath, K.; Araújo, M. P.; Batista, A. A.; Dinelli, L. R.; Oliva, G.; Castellano, E. E.; Ellena, J.; J. Chem. Soc., Dalton Trans. 2000, 19, 3383.

29. Wohnrath, K.; Garcia, J. R.; Nart, F. C.; Batista, A. A.; Oliveira Jr, O. N.; Thin Solid Films 2002, 402, 272.

30. Lin, X.Q.; Zhang, L.; Anal. Lett. 2001, 34, 1585.

31. Nicholson, R. S.; Shain, I.; Anal. Chem. 1964, 36, 706.

32. Marten, H.; Naes, T.; Multivariate Calibration, Wiley: Chichester, 1993.

33. Ferreira, M. M. C.; Antunes, A. M.; Melgo, M. S.; Volpe, P. L. O.; Quim. Nova 1999, 22, 724.

Received: June 13, 2006 Web Release Date: November 7, 2006 